\title{
Principle of Loyal Opposition: The Case of Political Parties in Nigeria's Fourth Republic
}

\author{
Olu Awofeso ${ }^{1} \&$ Paul A. Irabor ${ }^{2}$ \\ ${ }^{1}$ Department of Political Science, Obafemi Awolowo University, Ile-Ife, Nigeria \\ ${ }^{2}$ Department of Political Science, Kings University, Odeomu, Osun State \\ Correspondence: Paul A. Irabor, Department of Political Science, Kings University, Odeomu, Osun State. E-mail: \\ Pa.irabor@kingsuniversity.edu.ng
}

Received: September 28, 2018

Accepted: October 17, 2018

Online Published: November 16, 2018

doi:10.5539/jpl.v11n4p17

URL: https://doi.org/10.5539/jpl.v11n4p17

\begin{abstract}
Modern understandings of democracy not only suggest a regime in which those who govern are selected through contested elections, but more fundamentally, a system of government in which parties lose elections. Yet, the mechanism of vertical accountability whereby the people can hold the ruling government responsible depends on parties in opposition providing choices for voters while remaining loyal to the idea of governmental power. Adopting the principle of loyal opposition as the basis of this study in the Nigerian context, we try to interrogate whether the duty to serve as "government in-waiting" equally affects how the duty to critique the actions of the government is performed. The study further probed; can a ruling party cope with the criticism of the opposition party? To answer these questions, the study argued that it is tempting not to assume that, the institution of political party is still at its lowest ebb despite the successful democratic transition in Nigeria since 1999, and the alternation of political power resulting in the change of party in government from the People's Democratic Party to the All Progressives Congress in 2015. These issues have consequences for the principle of loyal opposition and democratic stability in Nigeria.
\end{abstract}

Keywords: political party, opposition party, ruling party, loyal opposition, legitimacy

\section{Introduction}

Evidence continues to highlight competition among political parties as one of the fundamental characteristics of a democratic regime (Adeola, 2014; Dahl, 1973; Salih and Nordlund, 2007). Since political parties are met to offer alternative policies which are often starkly opposed to one another, the principle of loyal opposition has become pertinent, not only as a means of testing the loyalty of the opposition party to the idea and practice of legitimate government but also for checking the excesses of the ruling party. The concept of loyal opposition connotes that groups or associations in the society may make constructive criticism against the governing party while remaining loyal to the idea/principle of government power (Anastaplo, 2004; Jung and Shapiro, 1995; Waldron, 2012). Loyal opposition therefore, is central to the running of political parties because opposition political parties reserves the right to contest election and hope for better luck next time (to take control of government power) when the winners policies are flawed, turn out to have been disastrous or unpopular in their implementation (Waldron, 2012). However, while this is true of most political parties across the globe, the lack of ideology in Nigerian parties leaves much to be desired as cross-carpeting and inter-party conflict seems rife (Agbaje and Adejumobi, 2006; Fashagba, 2014). Part of the criticism of lack of ideology of political parties in Nigeria is on the pursuit of selfish agenda by opposition parties to unseat the ruling party without clear cut idea of what to do in government. Thus, in spite of the criticism by the All Progressive Congress (APC) in the build up to the 2015 general election in Nigeria, it is just a political strategy to depose the People's Democratic Party (PDP) from political power (Awofeso and Irabor, 2017). This method of opposition politics defies the principle of loyal opposition. As Jennings puts it:

Irresponsible opposition is not part of democratic government, though many democratic states have never learned that lesson...system alone can produce a responsible opposition, one which is not anxious to win at the expense of ruining the game (Jennings, 1959: 49-50). 
Moreover, in what could be seen as the subterfuge and might of the then ruling party (PDP) over the opposition party was the controversy that arose over claims to the acronym 'APC' by two other political parties (African People's Congress and All Patriotic Citizens) in the build up to the 2015 general election. The claims were considered attempts by the PDP to thwart the successful alliance of the All Progressive Congress ahead of the general election (Owete, 2013). Given the central role of political parties and party politics in Nigeria, the essay therefore investigates the politicking of opposition party which led to change of party in government in the 2015 general election in Nigeria. It further examines the prospect of a ruling party to tolerate the criticisms of the opposition parties. This is with a view to examining the nexus between opposition politics and loyal opposition in a developing democratic country, like Nigeria.

\section{Perspectives on Political Party and Party System}

To have government in place in any society, there is bound to be political parties that are to contest vigorously to form such a government. Parties help with the formation of governments to the extent that it is possible to talk of party government (Schattschneider, 1942; Stoke, 1999). It is within this context that Hofmeister and Grabow (2011) assert that political party, being a social group, is characterized by a high degree of rational direction of behaviour towards ends that are objects of common acknowledgement and expectation. Political party is different from other social groups because of the functions it performs such as organising public opinion, communicating demands to the centre of governmental decision-making and political recruitment.

Political party has been described as any political group identified by official label and ideology that presents at elections, and is capable of placing through election, candidates for public office (Downs, 1957; Sartori, 1976). Likoti (2005) sees political party as an organised group of people with similar political aims and opinions that seek to influence public policy by getting its candidate elected to public office. However, studies have interrogated the claims of political party for promoting joint endeavors: to win election and dominate the organs of national leadership. It is contended that the interest of the dominant socio-political forces that saw to the formation of party will usually have overriding influences on relationships between various organs and structures of the party (Awofeso and Irabor, 2017; Ake, 1973; Doorenspleet, 2003). To this extent, political party have also been defined as a collection of people, a union of small groups dispersed through the country (branches, caucuses, local associations, etc.) and linked by coordinating institution (Awofeso and Irabor, 2017; Doorenspleet, 2003).

Party system reflects the pattern of relationships between individual parties in relation to each other (Hofmeister and Grabow, 2011). Generally, party systems may be grouped into three broad categories: one party system, two party system and multi-party system. In a dominant one-party system, one party is constantly in government and often governs alone. The general practice in a one-party system is to coalesce all the interest groups, ideological views and party loyalty into one mainstream. Since there is only one party in this system, studies (Odukoya, 2013; Rodee, 2000; Webb, David and Holliday, 2002) reveal that it does not give room for democratic stability of the country as the government may become absolute and dictatorial. In a two-party system, two parties of equivalent size compete for office, and each has a more or less equal chance of winning sufficient electoral support to gain executive monopoly (Rodee, 2000). Proponents of two-party system argue that government effectiveness is higher as it allows for a unified decisive leadership hence, coherent policies and fast decision making can be promoted (Burnell, 2001; Webb, David and Holliday, 2002). However, Lijphart (1999) contends that if the programmes of the two parties are both close to the political centre, they will be very similar to each other and, instead of offering a meaningful choice to the voters, are more likely to echo each other. Multi-party system provides for the existence of several political parties and as such, no party comes close to a majority status (Odaudu, 2012; Odukoya, 2013). Multi-party system in Nigeria have seen politics as a matter of "do-or-die affairs" as cases of intra and inter party conflict, cross carpeting and electoral violence etc. continues to impede party system institutionalization (Ake, 1973; Fashagba, 2014).

\section{Opposition Politics in Democratic System}

Although the study of opposition politics may be said to be rooted in Dahl's (1973) first systematic treatment of the subject, it has not been matched by comparable subsequent studies particularly in developing countries where one party is believed to dominate the political system and as a result, opposition politics remains an inadequately explored area of political science (Beyme, 1987; Lawson, 1993). Opposition politics denotes an organised partisan movement dedicated to opposing and possibly replacing an incumbent government (Adeola, and Akinyemi, 2014; Dolo, 2006; Jung and Shapiro, 1995). It is founded upon a system of elections and limited terms of office in the elected branches of the government. Such a system offers recognised opportunities for the challengers of those in political power. 
Jung and Shapiro (1995) argue that the role of opposition parties in democratic setting is threefold. The first is functional in that, should a government lose election, there is the possibility of a peaceful handover of political power among elites. Opposition parties are therefore sites for counter-elites to form and campaign as potential alternative governments. The second role of opposition is to legitimise the democratic political order. In this sense, institutional space is created to ensure that discontent and dissatisfaction can be directed at the government of the day rather than at the democratic regime itself. As such, the right to criticise and compete against the government is not forfeited. Lastly, opposition is to ensure the presence of healthy political debate. Opposition encourages competition over ideas among elites and counter-elites, which leads to demands for reason-giving and coherence in public debate (Lawson, 1993).

The prospect for institutionalisation and consolidation of opposition parties is a function of regime turnover through elections (International Institute for Democracy and Electoral Assistance, 2007). However, evidence suggests that Africans' commitment to democracy decays in the absence of alternation (Bratton, 2004). Lending credence to these positions, we could infer that the failure of a system to allow credible opposition in any democratic regime may limit the public's real choices for the emergence of a responsive and representative political system.

\section{Loyal Opposition}

In the democratic world, the principle of loyal opposition has evolved into two but mutually non-exclusive ideas. On the one hand, it presupposes opposition that is loyal to the democratic order rather than the government of the day. On the other hand, those who exercise political power are obliged to tolerate the opinions and the organised political efforts of all significant elements in the country (Anastaplo, 2004; Jung and Shapiro, 1995; Waldron, 2012). In essence, the continuing responsiveness of government to the preferences of its citizens, facilitated by opportunities for citizens to formulate their preferences and have these preferences weighed equally in the conduct of government depends on effective opposition that is loyal to the constitutional order (Anastaplo, 2004; Waldron, 2012). Opposition parties, therefore, through constructive criticism can replace the government of the country, a government that in turn will be opposed according to the same rules. The Government is thus put on notice that opposition are equipped and prepared to replace it.

The concept of loyal opposition dates back to 1826 in a debate in the British parliament of the term His Majesty's Opposition (Anastaplo, 2004). As Schmitz (1988:1013) puts it, "England invented the phrase, 'Her [or, His] Majesty's Opposition", being the first government which made a criticism of administration as much a part of the polity as administration itself. It was intended to illustrate that members of Parliament may oppose the policies of the incumbent government - typically comprising parliamentarians from the party with the most seats in the elected legislative chambers - while maintaining deference to the authority of the state and the larger framework within which democracy operates.

Evidently, there is no institution of opposition in presidential system of government compared to parliamentary system of government. Moreover, we locate a common ground why the principle is also applicable in presidential system of government as the case of Nigeria. First, there exists some positions in the roles of minority party and minority leader in the legislature (e.g. the position of minority party leader in the Nigeria National and Houses of Assembly). More so, the common practice with presidential system of government is that the ruling party assumes office through election contested by two or more parties. Thus, while the ruling party may exercise political power at the National level, opposition party may exist either at the State Executive level or National State Legislature. Furthermore, a change of government can also occur with a change of party in presidential system of government. For instance, the 2015 general election in Nigeria saw the emergence of the All Progressives Congress (APC) in place of the People's Democratic Party (PDP) who has been in government since 1999. No matter the position it finds itself (either existing at the National or State legislature/State Executive), what is important is that opposition party should scrutinise the government, hold them accountable for their decision, limit the extremity of the government's action, arouse public criticism of any dangerous policy, and make the government behave reasonably while maintaining loyalty to the legitimate government (Jennings, 1959; Schmitz, 1988).

In most developing countries like Nigeria, where politics is seen as a "dirty game", the principle of loyal opposition seems impracticable. The contending issue has been whether the ruling party can accommodate the (constructive) criticism of the opposition parties or whether the opposition parties, while serving as "government in-waiting" can adhere to the principle of loyal opposition.

\section{Loyal Opposition: Exploring Practical Discourse in Nigeria's Fourth Republic Parties}

$$
\text { ...a key component of democracy is the toleration of }
$$


dissent by the ruling party and dissenters do not engage in violating the rights of others and use of force, deception or fraud to pursue their interests and goals (Network of Ethiopian Scholars, 2005:6).

In view of the above quotation, we then ask, when should opposition parties be regarded as disloyal to the democratic order? On the other hand, how has the ruling party used political power to undermine or weaken the quality of opposition party? These posers set the pace for discourse in this section. The fact needs be restated that Nigeria operates a multi-party system, and until the 2015 general election which brought in the APC in control of political power, the PDP not only dominate the national government but also spread its tentacle in majority of the states for sixteen years. From 1999 till 2015, Nigeria's 36 States have experienced 125 Governors - both elected, impeached, and State Administrators. All these administrations have been under ten political parties while the PDP has produced the most Governors, as represented in the table below: 
Table 1. Political parties in government across the 36 States of Nigeria from 1999-2015

\begin{tabular}{|c|c|c|c|c|c|}
\hline State & 1999 & 2003 & 2007 & 2011 & 2015 \\
\hline Abia & PDP & PDP & PDP & PDP & PDP \\
\hline Adamawa & PDP & PDP & PDP & PDP & PDP \\
\hline Akwa Ibom & PDP & PDP & PDP & PDP & PDP \\
\hline Anambra & PDP & APGA & APGA & APGA & APGA \\
\hline Bauch & PDP & PDP & ANPP & PDP & APC \\
\hline Bayelsa & PDP & PDP & PDP & PDP & PDP \\
\hline Benue & PDP & PDP & PDP & PDP & APC \\
\hline Borno & ANPP & ANPP & ANPP & ANPP & APC \\
\hline Cross River & PDP & PDP & PDP & PDP & PDP \\
\hline Delta & PDP & PDP & PDP & PDP & PDP \\
\hline Ebonyi & PDP & PDP & PDP & PDP & PDP \\
\hline Edo & PDP & PDP & PDP & APC & APC \\
\hline Ekiti & $\mathrm{AD}$ & PDP & PDP & $\mathrm{ACN}$ & PDP \\
\hline Enugu & PDP & PDP & PDP & PDP & PDP \\
\hline Gombe & APP & PDP & PDP & PDP & PDP \\
\hline Imo & PDP & PDP & PDP & APGA & APC \\
\hline Jigawa & APP & APP & PDP & PDP & APC \\
\hline Kaduna & PDP & PDP & PDP & PDP & APC \\
\hline Kano & PDP & ANPP & ANPP & PDP & APC \\
\hline Kastina & PDP & PDP & PDP & PDP & APC \\
\hline Kebbi & APP & APP & PDP & PDP & APC \\
\hline Kogi & APP & PDP & PDP & PDP & PDP \\
\hline Kwara & ANPP & PDP & PDP & PDP & APC \\
\hline Lagos & $\mathrm{AD}$ & $\mathrm{AC}$ & $\mathrm{AC}$ & $\mathrm{ACN}$ & APC \\
\hline Nasarawa & PDP & PDP & PDP & $\mathrm{CPC}$ & APC \\
\hline Niger & PDP & PDP & PDP & PDP & APC \\
\hline Ogun & $\mathrm{AD}$ & PDP & PDP & $\mathrm{ACN}$ & APC \\
\hline Ondo & $\mathrm{AD}$ & PDP & PDP & LP & PDP \\
\hline Osun & $\mathrm{AD}$ & PDP & PDP & CAN & APC \\
\hline Oyo & $\mathrm{AD}$ & PDP & PDP & CAN & APC \\
\hline Plateau & PDP & PDP & PDP & PDP & APC \\
\hline Rivers & PDP & PDP & PDP & PDP & PDP \\
\hline Sokoto & APP & APP & PDP & PDP & APC \\
\hline Taraba & PDP & PDP & PDP & PDP & PDP \\
\hline Yobe & APP & APP & ANPP & ANPP & APC \\
\hline Zamfara & ANPP & ANPP & PDP & ANPP & APC \\
\hline
\end{tabular}

Source: African Elections Database, 2015.

While opposition parties such as the Action Congress of Nigeria (ACN), Congress for Progressive Change (CPC), Labour Party (LP) and All Progressives Grand Alliance (APGA) to mention but a few, struggle to assert their role by playing politics of criticism (albeit subjective in some ways) and providing choices for voters as 
alternative, electoral malpractices represents part of a more general scheme of the PDP to force opposition parties into the ruling party, thereby weakening the opposition parties and governing without constraints. The control of the nation's security apparatus, unopposed access to vast resources and the power of appointing electoral commission officials, being the preserve of the ruling party in presidential system of government, enable the PDP to skew and manipulate elections in their favour (Omilusi, 2017). Further study reveals that the military idiosyncrasy of the former President, Olusegun Obansanjo, paves the way for the PDP to consolidate political power for sixteen years (Cooke, 2015). Since politics in Nigeria is often played out as zero-sum game where anything other than to gain political power is not considered worthwhile, political opponents usually had no choice than to join the ruling alliance or suffer exclusion and lack of access to resources (Awofeso and Irabor 2016; Okechukwu and Andrew, 2014).

During the build up to the 2015 general election, public cynicism against perceived PDP ineffective governance, rampant corruption of public officials and insecurity had risen; and moreover, the crisis in the PDP had degenerated into factions (Gbadegesin, 2015; Okohue, 2013; Omilusi, 2017). Opposition parties were to take advantage of the rising development for a change of party in government, and on July 31st 2013, the Independent National Electoral Commission approved the application of four political parties (ACN, CPC, ANPP and a faction of APGA) to merge into one to be known as the All Progressive Congress (APC). Awofeso and Irabor (2017) described this step as a calculated attempt of the opposition parties to garnered more support over the PDP to win the 2015 general election. Indeed, attempt was made by the PDP to thwart the successful alliance of the opposition parties. It was reasoned that the claimed to the acronym "APC' by two political parties (African People's Congress and All Patriotic Citizens) was an attempt by the PDP to foil the merger against the background of massive defection of a faction of PDP (New PDP) to the APC and the public support the APC had gained during electioneering campaign (Owete, 2013). According to Gbadegesin (2015), the change campaign slogan of the APC resonated, with a substantial majority of Nigerians culminating in the historical defeat of an incumbent president for the first time in Nigeria history.

On the other hand, what could be seen as inordinate ambition of the APC was exhibited to depose the PDP from government at all cost. One of the conditions for understanding opposition politics as postulated by Ebienfa (2014) is, among other factors, the individuals and groups that criticise the programmes and policies of the ruling party. It is within this context that we tend to analyse the ideology and policies of the APC and the series of defections and cross-carpeting that accompanied the 2015 general election. It is one matter to criticise, and quite another to offer an alternative. When asked how the APC policies would differ from those of PDP during the 2015 electioneering campaign, the former National Publicity Secretary of the APC, Alhaji Lai Mohammed was quoted to have said:

I'll be very frank. I don't think the PDP really has any policies...Remember, our party is a product of the merger of three independent opposition political parties and this is what is going [to] make this particular election different from other elections. Until now, the ruling party [then PDP] has enjoyed a free ride, there has been no effective opposition because there were only small regional, ethnic-based parties. But after almost 15 years, the leaders of the small parties came to the conclusion that to get the PDP out of power, to change the status quo, we must come together to give the ruling party a run for its money (Punch Newspaper, 2015:10).

With the recent crisis the APC is embroiled, it is not surprising that the party had not taken time to understand its ideology through which it intend to implement its "change policies" as politicians continue to decamp from the party to another party. Gbadegeshin (2015:48) succinctly put the APC scenario thus:
...But since its assumption of responsibility for the running of the nation, it [APC] has struggled with its own inner demons, to the delight of its main rival [PDP]. It appears that the party of change has not been well prepared for the discipline that it takes to govern with a mission of change.

Adesola and Akinyemi (2014) maintain that the most advanced method of opposition politics similar to Western type are parties that put the ruling party "on its toes". This is regarded as the Western style of party competition that can encourage party institutionalisation in the absence of friction among the organs in a political system for a long period (Adeola, 2014). Against this background was the height of hate-speech in the run-up to the 2015 elections, 
was tense and acrimonious, as both the PDP and the APC hurled insults and accusations against each other. A principal aspect of this discussion was the declarative insults directed to the former President (Goodluck Jonanthan) during the 2015 electioneering campaign. Olawale (2015:15) vividly recounts Rotimi Fashakin a Chieftain in APC) thus:

\begin{abstract}
The president is clueless as much as confused...This government has lost its mind and its bearing. The president is leading Nigeria on the road to hell and on the path to Kigali. He need[s] to learn that governance demands more than his slothful approach to issues that affects the common man....People no longer believe in this government again to protect them. We [APC] are fully ready and prepared to govern come $2015 \ldots$ But let me warn, PDP should get prepared for grave and far-reaching consequences if the forthcoming election is mar with irregularities because as I speak, plans are ongoing to ensure that the election is inconclusive and we cannot close our eyes against it.
\end{abstract}

The above quotation makes mockery of a legitimate government and typifies act of desperation of the APC with no issue-based criticism to offer the electorate. The treatment of such speech as criminal in the view of Anastaplo (2004) is based on the dangers in it; it is likely to undermine confidence in government policies and in the official incumbents.

\title{
6. From Opposition Party to Ruling Party: Has the APC Fair Better?
}

Since the assumption of the APC-led government in 2015 as the ruling party, nonetheless it "change" slogan, the government have had to deal with challenging issues such as rising cost of living and the dollar, increase in the pump price of petroleum product, herdsmen's crisis, continual terrorist attacks in the Northeast, just as political corruption remains unabated (Jubril, 2017; Omilusi, 2017). A comparison of Goodluck Jonathan's PDP administration and Muhammadu Buhari's APC administration is put in a table below:

Table 2. Comparing Jonathan with Buhari Administration

\begin{tabular}{l}
\hline Goodluck Jonathan's PDP Administration \\
\hline Price of fuel per liter was sold for N87 \\
N1bn was budgeted for feeding in Aso-Rock in 2011, \\
and N517m in 2015 \\
N1.4bn was used to service presidential jets in one \\
year
\end{tabular}

An average of N8million was spent on each international trip

According to the Federal Bureau of Statistics, over 5.8 millon jobs was created in 5years

Naira exchange rate was at $\mathrm{N} 185$ to $\$ 1$

\section{Muhammadu Buhari's APC Administration}

Price of fuel per liter is sold for N145

N1.7billion was budgeted for same in 2016

N6bn was used to service presidential jets within 6 month of the administration

An average of N55million is expended on each international trip.

According to the Federal Bureau of Statistics, over 2 million workers were sacked in 8 months.

Naira exchange rate sells at N315 to $\$ 1$

Source: Nairaland Forum; Comparing Jonathan with Buhari Administration-Politics, Sunday, 06th March 2016)

Emerging trends in the country seem to portray the anti-corruption war of the ruling APC as mainly targeted at opposition politicians, a ploy targeted to silence opposition politics of the PDP. While the Economic and Financial Crimes Commission (EFCC) has gone after PDP bigwigs like the former Governor of Jigawa state, Sule Lamido, former National Security Adviser, Sambo Dasuki and former PDP National Publicity Secretary, Olisa Metuh, on account of corruption and embezzlement of public funds when in government, APC stalwarts accused of the same financial crimes like the former Governor of River state, Rotimi Amaechi, former Governor of Bayelsa state, Timipre Sylva, former Governor of Anambra state, Chris Ngige, etc were not prosecuted (Aribisala, 2015). Much more than the membership base of a party in terms of quantity of members, the quality and viability of a 
party in terms of ideological stance, manifesto and organisational structure should be considered as a means to an end. In view of this position, Awofeso and Irabor, (2017) as well Ebije (2017) opine that the merger of political parties (ACN, CPC, ANPP a faction of APGA and PDP) which produced the APC could impede the existence of a viable opposition party in Nigeria. With the combined force of these four parties, a supposedly multi-party system may coalesce to two party system where there exists a dominant ruling party and a weak opposition party. Similarly, since political parties are formed by individuals that share the same political ideology, and that hold common vision and mission statement, it could be observed that the lack of ideology in Nigeria political parties might be the major bane of intra-party conflict currently manifesting in the ruling APC. Thus, the APC can be related to the Tower of Babel, and like it was in ancient time, building the change mantra Tower would certainly be an impossible task.

It is tempting to assume that the success of the APC in the 2015 general election is because of the number of supporters it could garnered through the merging of different political parties. We try to negate this assumption with Michels' (1942) Iron Law of Oligarchy through which modern democratic societies and the most advanced parties have been unable to escape. He avers that revolutions sometimes occur in history when the aristocracy becomes corrupt and inefficient, not because the masses have objection to being ruled by aristocracy but would like to be ruled by another aristocracy. We could infer from this position that the political climate during the 2015 general election was ripe for a new set of oligarchy to replace the PDP oligarchy. It was neither because the APC is an "alternative government" in the true sense of the word nor because the number of members it could garnered through the merging of parties. In essence, the ruling oligarchy of the APC, just like the PDP, may later be replaced by another set of oligarchy. True to this perception is the speculation circulating about the formation of a mega party by the PDP and other minority parties to challenge the perceived domination of the APC; there seems to be no end in sight to the politics of alignment and re-alignment in Nigeria politics. While the game of number is not to be undermined in game politics, opportunity abound for party discipline and party coherence with less desperation of parties when opposition party win election without forming coalition against the ruling party.

\section{Conclusion}

The hope for the party that can offer a viable and constructive criticism against the ruling APC lies on the PDP because of its membership base and the fact that it held sway as the ruling party from 1999 to 2015. The PDP should conduct itself with the understanding that the country is more worthy of allegiance than the ambitions of gaining political power from the APC. While ambition is not ruled out, it should be an ambition to be recognised as a viable opposition. Moreover, the APC should learn to cope with the criticism of the opposition parties. Certain principles and ends are presupposed, standards that are far more important than the politics of consolidating political power. More so, there should be opportunity for opposition parties to hold and air their contrasting views freely without any form of intimidation.

\section{References}

Adeola, G. (2014). Robust Opposition Political Party: A Necessary Institution for Democratic Sustainability in Nigeria. In G. L. Adeola (Ed.), Opposition Political Parties and Democratisation in Africa. Lagos, ADLA Communications Limited.

Adesola, F., \& Akinyemi, L. (2014). Security of Lives of Opposition Elements in Nigeria. In G. L. Adeola (Ed.), Opposition Political Parties and Democratisation in Africa. Lagos, ADLA Communications Limited.

African Elections Database. (2015). Elections in Nigeria. Retrieved 2017, from http://africanelections.tripod.com/ng.html

Agbaje, A., \& Adejumobi, S. (2006). Do votes count? The travail of electoral politics in Nigeria. Journal of Africa Development, 33(3), 25-44.

Ake, C. (1973). Explaining Political Instability in New States. The Journal of Modern African Studies, 11(3). https://doi.org/10.1017/S0022278X00008478

Anastaplo, G. (2004). Loyal Opposition in a Modern Democracy. Loyola University Chicago Law Journal, (35), 4.

Aribisala, F. (2015). APC body-language of witch-hunting the PDP. Vanguard Newspaper, November 3, pp. 6.

Awofes, O., \& Irabor, P. (2017). The Game Theory and the Politics of Cross-carpeting in Nigeria. Public Policy and Administration Research, 7(7), 66-72.

Awofeso, O., \& Irabor, P. (2016). Party Cross-carpeting in Nigeria's Fourth Republic: Cases and Causes. Journal of Public Administration and Governance, 6(3), 31-40. https://doi.org/10.5296/jpag.v6i3.10000 
Ayoade, J. (2008). Election Administration in Nigeria and the Challenges of the 2007 Election. Tsoc sci, 2(2), $142-151$.

Beyme, K. (1987). Parliamentary Oppositions in Europe. In E. Kolinsky (Ed.), Opposition in Western Europe. London, Croom Helm.

Bratton, M. (2004). The Alternation Effect in Africa. Journal of Democracy, 15(4), 147- 158. https://doi.org/10.1353/jod.2004.0059

Burnell, P. (2001). The Party System and Party Politics in Zambia: Continuities Past, Present and Future. ECPR Workshop party, Party Systems and Democratic Consolidation in Third World', Grenoble, 6-11 April. https://doi.org/10.1093/afraf/100.399.239

Cooke, J. (2015). Nigerians Have Voted, Will Political Leaders Listen? Center for Strategic and International Studies.

Dahl, R. (1973). Polyarchy, Participation and Opposition. New Haven: Yale University Press.

Dolo, E. (2006). Opposition parties: Benefits and Challenges in Building Democracy. The Perspective, Atlanta. $1-8,20$ October.

Doorenspleet, R. (2003). Political Parties, Party Systems and Democracy in Sub-Saharan Africa. In M. A. Mohamed Salih (Ed.), African Political Parties Evolution, Institutionalisation and Governance. Sterling: Pluto Press.

Downs, A. (1957). An Economic Theory of Democracy. New York: Harper \& Brothers.

Ebienfa, I. (2014). Opposition Politics and Leadership Infidelity in Africa. In G. L. Adeola (Ed.), Opposition Political Parties and Democratisation in Africa. Lagos, ADLA Communications Limited.

Ebije, I. (2017). Nigeria's Confused Political Parties. The Sun Newspaper, March 30 pp. 10.

Fashagba, J. (2014). Party Switching in the Senate under Nigeria's Fourth Republic. The Journal of Legislative Studies, 20(4), 516-541. https://doi.org/10.1080/13572334.2014.926169

Gbadegesin, S. (2015). Ministers and Challenge of Change. The Nation, November 13 pp. 6.

Hofmeister, W., \& Grabow, K. (2011). Political Parties: Functions and Organisation in Democratic Societies. Singapore: Konrad Adenauer Stiftung.

Ihonvbere, J. O. (2004). The Obasanjo Second Term in Office: Reinventing and Repositioning Nigeria for Growth, Stability and Democracy. Retrieved 26 May, 2017, from www.westafricareview.com/issue6/ihonvbere.html

International Institute for Democracy and Electoral Assistance. (2007). Political Parties in Africa: Challenges for Sustained Multiparty Democracy. Africa Regional Report Based on Research and Dialogue with Political Parties.

Jennings, I. (1959). Parliament. Cambridge University Press.

Jubril, O. (2017). Is PDP failing as an opposition party? Vanguard Newspaper, February, 15.

Jung, C., \& Shapiro, I. (1995). South Africa's Negotiated Transition: Democracy, Opposition and the New Constitutional Order. Politics \& Society, 23(2). https://doi.org/10.1177/0032329295023003002

Lawson, S. (1993). Conceptual Issues in the Comparative Study of Regime Change and Democratization. Comparative Politics, 25, 2. https://doi.org/10.2307/422351

Lijphart, A. (1999). Patterns of Democracy. Government Forms and Performance in Thirty- Six Countries. New Haven and London: Yale University Press.

Likoti, F. (2005). Investigating Intra-Party Democracy in Lesotho: Focus on Basutoland Congress Party and Basuto National Party, EISA Occasional Paper Series, NO 39.

Michels, R. (1942). Political Parties. Glencoe III, The Free Press.

Nairaland, (2017). Comparing Jonathan with Buhari Administration-Politics. Retrieved from http://www.nairaland.com/2974957/comparing-jonathan-administration-buhari-administration

Network of Ethiopian Scholars. (2005). Scandinavian Chapter Press Release No.6, June 30 Published in Sudan Tribune, June 30.

Obi, A. (2015). Why is Lai Mohammed Struggling? The Sun Newspaper, December 31. 
Odaudu, D. (2012). Political Parties and Democratic Sustenance in Nigeria. A Journal of Representative Democracy, 2.

Odukoya, A. (2013). Party System and Political Conflicts in Nigeria's Fourth Republic. In A. S. Obiyan, \& K. Amuwo (Eds.), Nigeria's Democratic Experience in the Fourth Republic since 1999: Policies and Politics. Maryland: University Press of America.

Okohue, P. (2013). Cost of Resolving PDP Crisis”. Daily Newswatch. Retrieved September 20, 2013, from http://www.mydailynewswatchng.com/2013/09/18/cost_resolving_pdpcrisis

Olawole, A. (2015). Jonathan Leading Nigeria to destruction- Rotimi Fashakin. Premium Times, January 12th.

Omilusi, M. (2017). Putting Government on its Toes: A Vociferous Opposition Party and the Lai Mohammed Phenomenon in Nigeria's Electoral Politics. International Journal of politics and Good Governance, $\operatorname{VIII}(8)$.

Owete, F. (2013). INEC, All Progressives Congress Meet over APC. Premium Times. Punch Newspaper. (February, 2015). Nigeria: Al Haji Lai Mohammed, National Public Secretary, APC Talks About the Party Policies Should it Win Election. Retrieved March 25, 2013, from www.punchninigeria.com/nigeria-al-haji-lai-mohammed-national-public-secretary-apc

Rodee, A. (2000). Introduction to Political Science (4th ed.). Auckland: MaGrew Hill Intel.

Salih, M., \& Nordlund, P. (2007). Political Parties in Africa: Challenges for Sustained Multiparty Democracy. Africa Regional Report Based on Research and Dialogue with Political Parties. International IDEA: Stockholm.

Sartori, G. (1976). Parties and Party Systems. A Framework for Analysis. Cambridge: Cambridge University Press.

Schattschneider, E. (1942). Party Government. New York: Rinehart.

Schmitz, G. (1988). The Opposition in a Parliamentary System. Parliamentary Research Branch, Library of Parliament.

Stoke, C. (199). Political Parties and Democracy. Annu. Rev. Polit. Sci., 2, $243-67$. https://doi.org/10.1146/annurev.polisci.2.1.243

Webb, D., David M. F., \& Holliday, L. (2002). Political parties in advanced industrial democracies. Oxford: Oxford University Press. https://doi.org/10.1093/0199240566.001.0001

\section{Copyrights}

Copyright for this article is retained by the author(s), with first publication rights granted to the journal.

This is an open-access article distributed under the terms and conditions of the Creative Commons Attribution license (http://creativecommons.org/licenses/by/4.0/). 